\title{
Cellular processing in the SW1222 cell line of mAb A33 directly and indirectly radiohalogenated
}

\author{
JOHANNA HÖGLUND ${ }^{1,2}$, ANNA ORLOVA ${ }^{2}$, ANDERS SUNDIN ${ }^{1}$, \\ HANS LUNDQVIST $^{2}$ and VLADIMIR TOLMACHEV ${ }^{2}$
}

\author{
Divisions of ${ }^{1}$ Radiology and ${ }^{2}$ Biomedical Radiation Sciences, Department of Oncology, \\ Radiology and Clinical Immunology, Uppsala University, Uppsala, Sweden
}

Received December 20, 2005; Accepted March 2, 2006

\begin{abstract}
Investigations into the cellular processing of radiolabeled monoclonal antibodies (mAbs) for their further use in radioimmunodiagnosis and cancer therapy are needed in order to understand the fate of internalized and catabolized mAbs. The anti-colorectal cancer mAb, A33, was labelled with ${ }^{76} \mathrm{Br}$ and ${ }^{125} \mathrm{I}$ using the direct Chloramine-T method, or by labelling $N$-succinimidyl para-(tri-methylstannyl) benzoate and its further conjugation to the mAb. The cellular processing of the four conjugates was investigated in SW1222 cells in vitro. Uptake of mAb was rapid, peaking after 14-16 h. Intracellular degradation was slow and the early loss of radioactivity was due to dissociation of cell-surface bound $\mathrm{mAb}$. The indirect labelling resulted in stronger binding of the mAb as well as prolonged intracellular retention of the radiolabel. Direct and indirect halogen radiolabelling results in different cellprocessing patterns of radiolabels, and radioactive catabolic products follow different routes of cellular excretion. The results of this cellular study indicate that indirect labelling is preferable to the direct Chloramine-T method.
\end{abstract}

\section{Introduction}

Positron emission tomography (PET) is increasingly used for tumour visualization. Detection sensitivity is higher for PET in comparison with single photon emission computerized tomography. It was shown that the use of tumour-specific agents such as monoclonal antibodies (mAbs) directed against tumourassociated antigens and radiolabelled with positron emitters may result in more specific detection than with widely spread non-tumour-specific PET targeting agents such as $\left[{ }^{18} \mathrm{~F}\right] \mathrm{FDG}$

Correspondence to: Dr Vladimir Tolmachev, The Rudbeck Laboratory, Division of Biomedical Radiation Sciences, S-751 85 Uppsala, Sweden

E-mail: vladimir.tolmachev@bms.uu.se

Key words: ${ }^{76} \mathrm{Br}$, indirect labeling, antibody internalization, cellular processing and $\left[{ }^{11} \mathrm{C}\right]$ methionine (1). Labelling of mAbs for PET radioimmuno diagnosis requires positron-emitting nuclides with half-lives longer than the conventional ${ }^{11} \mathrm{C}$ and ${ }^{18} \mathrm{~F}\left(T_{1 / 2}=20\right.$ and $110 \mathrm{~min}$ ) that can readily be attached to proteins. The radiohalogens ${ }^{76} \mathrm{Br}$ and ${ }^{124} \mathrm{I}$ have been suggested as suitable candidates for this purpose (2-4) by virtue of its decay halflife and reasonable positron yield $\left(T_{1 / 2}=16.2 \mathrm{~h}\right.$ and $55 \%$ for ${ }^{76} \mathrm{Br}$ and $T_{1 / 2}=4.2$ days and $55 \%$ for ${ }^{124} \mathrm{I}$ ) as well as the established and simple direct and indirect radiohalogenation of proteins (5-8). Indirect radiohalogenation of proteins seems preferable because it was found that catabolism of directly radiohalogenated mAbs resulted in high amounts of free radiohalogene, which had a slow excretion rate (bromine) (5) or accumulated in normal tissue (iodine) (9).

We are planning to introduce $\mathrm{A} 33 \mathrm{mAb}$ for radioimmuno diagnosis and therapy of colorectal cancers $(10,11)$. The expression of the colon-cancer antigen, A33, appears to be organ specific, with the large and small intestinal mucosa as the principal sites of expression. An almost uniform tumour expression of the A33 antigen has been found in $95 \%$ of primary and metastatic colorectal cancers, while other epithelial cancers, sarcomas, neuroectodermal cancers and lymphoid neoplasms are generally A33-negative (12). The antigen is not secreted or shed and some human colon cancer cell lines have shown high levels of antigen expression, binding up to 370,000 A33 antibodies per cell (4). For this reason, this antibody might be a useful targeting vector in radioimmuno diagnosis. However, there are indications of non-typical cellular processing of the mAb A33 $(13,14)$, possibly invalidating general considerations about tracer design and processing.

Introduction of the new radiolabelled protein in clinical practice requires detailed study (15) including labelling chemistry, cellular processing, radiocatabolits, and pharmacokinetic. The aim of the present study was to further characterize the cellular processing of mAb A33 labelled with radiohalogens ${ }^{76} \mathrm{Br}$ and ${ }^{125} \mathrm{I}$ by using the conventional direct Chloramine- $\mathrm{T}$ (CAT) method and the indirect procedure with $\mathrm{N}$-succinimidyl para-(tri-methylstannyl) benzoate (SPMB) as the precursor molecule $(5,7)$. Studies were carried out on the A33-antigen positive SW1222 cell line. The four conjugates were analyzed regarding cellular uptake and retention. Furthermore, excreted catabolites were analyzed to identify the distribution of high and low molecular weight components. 


\section{Materials and methods}

Antibodies and cells. The CDR-grafted huA33 antibody (9 mg/ $\mathrm{ml}$ in phosphate buffer (50 mM, pH 7.0) with $154 \mathrm{mM} \mathrm{NaCl})$ (16) and the colorectal cancer cell line, SW1222, expressing the A33 antigen (17) were kindly donated by the Ludwig Institute (New York, NY, USA). The cells were counted with an electronic cell counter (Beckman Coulter, Bromma, Sweden). Cells were plated in culture dishes $(\varnothing 3.5 \mathrm{~cm})$; at the time of the experiments, the number of cells per dish was $0.7-1 \times 10^{6}$. Cells were washed once with complete culture medium before the radioactive medium ( $1 \mathrm{ml}$ per dish) was applied. The radioactive medium contained $0.2 \mu \mathrm{g} \mathrm{mAb} / \mathrm{ml}$ $\left(30-60 \mathrm{kBq}{ }^{76} \mathrm{Br}\right.$ or $\left.15-30 \mathrm{kBq}{ }^{125} \mathrm{I}\right)$. For each data-point three cell dishes were used, and experiments were repeated three times.

Chemicals. All chemicals and reagents were of analytical grade. CAT and sodium metabisulfite (Sigma Chemical Co., St Louis, MO, USA) were used as $10 \mathrm{mg} / \mathrm{ml}$ aqueous solutions. The precursor, SPMB, was synthesized according to Koziorowski et al (18).

Radioactivity measurements, radionuclides and radiolabelling of $m A b A 33$. The radioactivity was measured using either an ultra-pure germanium detector with multi-channel analyzer (ORTEC, The Nucleus, Inc., Oak Ridge, TN, USA) working on-line with a PC, or an automatic gamma counter (Wallac, Upplands-Väsby, Sweden) using a ${ }^{76} \mathrm{Br}$ measurement protocol with an energy window of 300-2047 keV and a ${ }^{125} \mathrm{I}$ standard protocol.

The production of ${ }^{76} \mathrm{Br}$ was carried out at a low-energy cyclotron (MC17, Scanditronix, Uppsala, Sweden) at the Uppsala University PET Centre according to a method described previously (19). [ $\left.{ }^{125} \mathrm{I}\right] \mathrm{NaI}$ was purchased from Amersham Pharmacia Biotech UK Limited (Buckinghamshire, UK).

Direct and indirect radiohalogention was performed as described elsewhere $(5-7,10)$. Directly $\left({ }^{125} \mathrm{I}-\mathrm{A} 33,{ }^{76} \mathrm{Br}-\mathrm{A} 33\right)$ and indirectly labelled mAb ([$\left.{ }^{125} \mathrm{I}\right] \mathrm{PIB}-\mathrm{A} 33$ and $\left.\left[{ }^{76} \mathrm{Br}\right] \mathrm{PBrB}-\mathrm{A} 33\right)$ were purified on Sephadex G-25 NAP-5 columns (Pharmacia, Uppsala, Sweden) equilibrated with PBS.

Analysis of cell culture medium. After cell incubation, the cell culture medium was analyzed regarding the amount of radioactivity released and size of degradation products. Half$\mathrm{ml}$ samples of the cell culture medium were aspirated and separated into high and low molecular weight (HMW and LMW) fractions on NAP-5 columns. The radioactivity of the fractions was then determined using the gamma well-counter.

Continuous incubation with radioactive media. Radioactive medium was added to the dishes and the cells were incubated at $37^{\circ} \mathrm{C}$ from $30 \mathrm{~min}$ up to $48 \mathrm{~h}$. At various time-points, celldishes were taken to analyze membrane-bound and internalized radioactivity as described elsewhere (20). Additional dishes were incubated 1-48 $\mathrm{h}$ with an excess of unlabeled $\mathrm{mAb}$, $12 \mu \mathrm{g}$ per dish, to determine unspecific binding.

Interrupted incubation with radioactive medium. Radioactive medium was added to the dishes and the cells were incubated
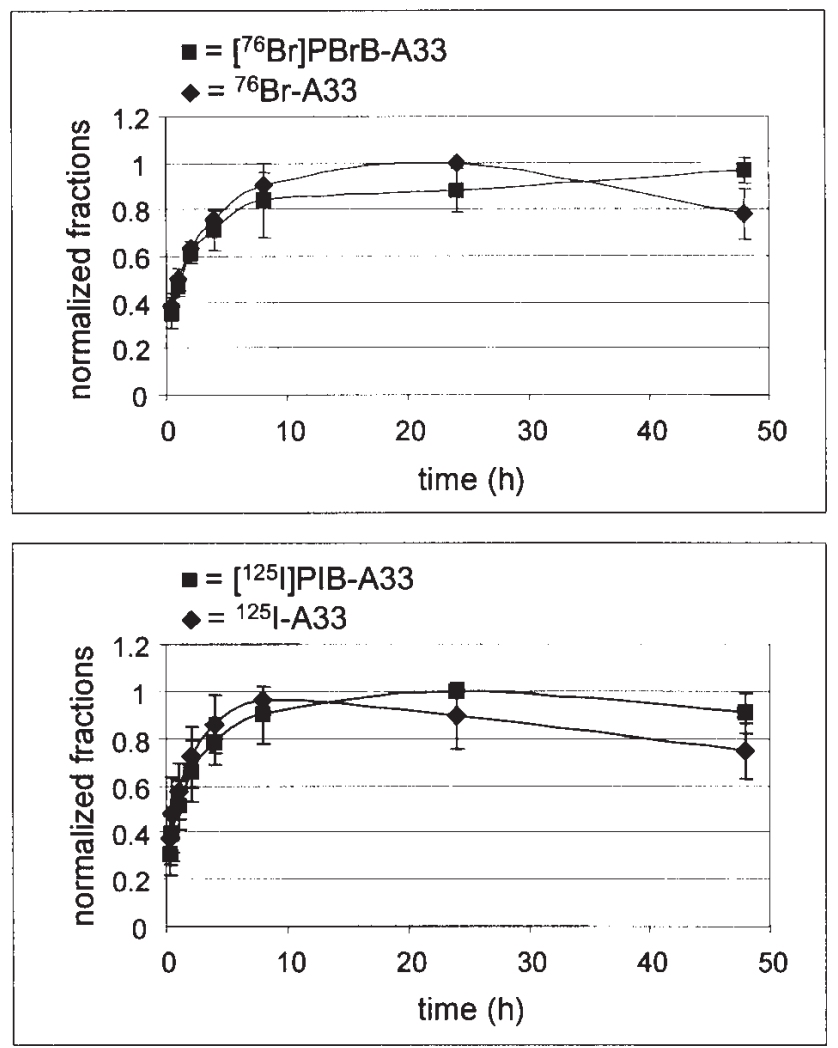

Figure 1. Uptake as a function of time for the four conjugates: (A) ${ }^{76} \mathrm{Br}-\mathrm{A} 33$

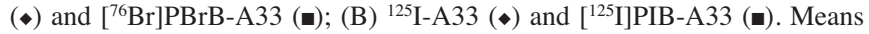
and maximum errors are shown for 3 or 4 experiments, each performed in triplicate.

at $37^{\circ} \mathrm{C}$ for $12-13 \mathrm{~h}$. Incubation was interrupted by washing the dishes six times with ice-cold serum-free medium. Fresh, complete medium at $37^{\circ} \mathrm{C}$ was added, $1 \mathrm{ml}$ per dish, and the cells were again incubated at $37^{\circ} \mathrm{C}$. At various time-points, from $0-24 \mathrm{~h}$, the incubation medium was aspirated from celldishes for size exclusion chromatography. The cells were then analyzed for membrane-bound and internalized radioactivity.

Cellularly processed $m A b$. In order to evaluate the processing of internalized radioactivity, cells after interrupted incubation with radiolabelled $\mathrm{mAb}$ were incubated with $12 \mu \mathrm{g}$ nonlabelled $\mathrm{mAb}$ at $4^{\circ} \mathrm{C}$ for $4 \mathrm{~h}$ in order to displace membranebound radioactive $\mathrm{mAb}$. Cells were washed with cold media and, after addition of $1 \mathrm{ml}$ fresh media, were incubated at $37^{\circ} \mathrm{C}$. At various time-points, $0-24 \mathrm{~h}$, incubation medium was aspirated from the cell-dishes and analyzed by size exclusion chromatography. The cells were then washed six times with ice-cold serum-free culture medium and analyzed for membrane-bound and internalized radioactivity.

\section{Results}

Continuous incubation with radioactive media. The cellular uptake of the four conjugates as a function of time was studied; the results are shown in Fig. 1, where 1.0 represents maximum uptake. The uptake pattern was rather similar for the four conjugates although the absolute uptake was higher for indirectly labelled mAb ([76 $\mathrm{Br}] \mathrm{PBrB}-\mathrm{A} 33$ and $\left.\left[{ }^{125} \mathrm{I}\right] \mathrm{PIB}-\mathrm{A} 33\right)$ than for 
(A) $\left[{ }^{76} \mathrm{Br}\right] \mathrm{PBrB}-\mathrm{A} 33$

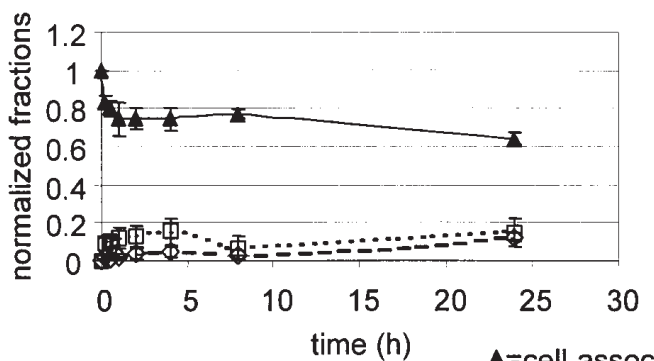

(B) [125]]P|B-A33

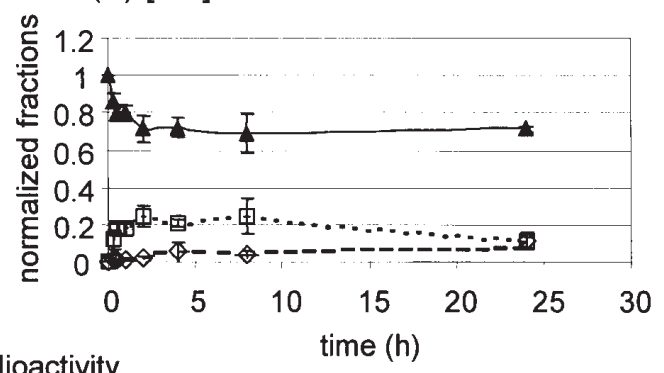

$\square=$ released HMW radioactivity

$\diamond=$ released LMW radioactivity

(D) ${ }^{125 \mid-A 33}$

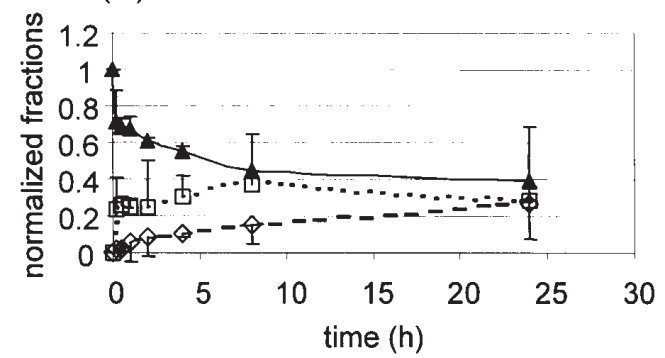

Figure 2. Release of radioactivity from cells as a function of time for the four conjugates $\left[{ }^{76} \mathrm{Br}\right] \mathrm{PBrB}-\mathrm{A} 33$ (A), $\left[{ }^{125} \mathrm{I}\right] \mathrm{PIB}-\mathrm{A} 33$ (B), ${ }^{76} \mathrm{Br}-\mathrm{A} 33$ (C) and ${ }^{125} \mathrm{I}-\mathrm{A} 33$ (D). $\Delta--\mathbf{\Lambda}$, total cell-associated radioactivity; $\diamond--\diamond$, low molecular weight; and $\square \cdots \square$, high molecular weight released radioactive products. Means and maximum errors are shown for 3 experiments, each performed in triplicate.

directly labelled mAb ( ${ }^{76} \mathrm{Br}-\mathrm{A} 33$ and $\left.{ }^{125} \mathrm{I}-\mathrm{A} 33\right)(20-60 \%$ and $10-20 \%$ from added radioactivity, respectively). A tendency toward a decreased cell-associated radioactivity at the latest time-point ( $48 \mathrm{~h}$ ) was seen for both brominated and iodinated conjugates in the case of directly labelled mAb. Furthermore, the membrane-bound radioactivity corresponded to approximately two-thirds and internalized approximately one-third of the total cell-associated radioactivity throughout the study (data not shown). The background invariably accounted for less than $10 \%$ of the total cell-associated radioactivity.

Interrupted incubation with radioactive media. The cellular retention of radioactivity after interrupted incubation with the four conjugates was studied; the results are shown in Fig. 2. Retention of indirectly labelled mAb (Fig. 2A and B) was more pronounced than that of directly labelled mAb (Fig. 2C and D), $64-72 \%$ vis-à-vis $39-44 \%$ cell-associated radioactivity after $24 \mathrm{~h}$ for indirectly and directly radiohalogenated $\mathrm{mAb}$ respectively. Initially, a quick release of radioactivity was observed, $25-28 \%$ and $40-45 \%$ of initially bound, for indirectly and directly radiolabelled $\mathrm{mAb}$, respectively. This early decrease in cell-associated radioactivity (completed within $4 \mathrm{~h}$ ) was almost entirely due to a release of membrane-bound radioactivity (data not shown). The release of radioactivity from the cells showed a bi-exponential pattern, with a rapid early and a slower late phase. The $T_{1 / 2}$ (early) was less than $20 \mathrm{~min}$ for all four conjugates, whereas the $T_{1 / 2}$ (late) was several days. Furthermore, the $T_{1 / 2}$ (late) was longer for the indirectly labelled conjugates, 5-48 days, compared with the directly labelled mAbs, with a $T_{1 / 2}$ (late) of 1-2 days. The released radioactivity as measured in the cell-culture medium was, for all four conjugates, to the greatest extent in HMW form until the latest time-point when the amounts of HMW and LMW radioactivity were alike. Furthermore, the release of LMW radioactivity was slower in the case of indirectly vs. directly labelled mAb.

Cellularly processed $m A b$. The excretion pattern of degradation products was assessed after interrupted incubation, with subsequent displacement of cell-surface bound mAb. Results of the cellular excretion of radioactivity and of the analysis of degradation products are shown in Fig. 3. In the case of direct labelling, the retained intracellular radioactivity was $29-31 \%$ after $24 \mathrm{~h}$, whereas for indirect labelling it was 49-61\%. The two indirectly labelled conjugates (Fig. 3A and B) revealed similar excretion patterns, with a somewhat higher fraction of HMW radioactivity at the start of incubation but with augmented release of LMW radioactivity over time. The two directly labelled conjugates (Fig. 3C and D) also showed similar excretion patterns, but LMW radioactivity was released to a significantly greater extent in the case of directly vis-à-vis indirectly labelled mAb. A part of the excreted radioactivity was in HMW form also in the case of directly labelled mAb.

\section{Discussion}

The studies presented were carried out on the A33-antigen positive SW1222 cell line. We investigated the cellular processing of the four radiolabelled conjugates, mAb A33 directly or indirectly radiohalogenated with ${ }^{76} \mathrm{Br}$ and ${ }^{125} \mathrm{I}$. The fate of the radiolabels was analyzed as regards cellular uptake and retention. The excreted catabolites were further analyzed to identify the distribution of high and low molecular weight components. 
(A) $\left[{ }^{76} \mathrm{Br}\right] \mathrm{PBrB}-\mathrm{A} 33$

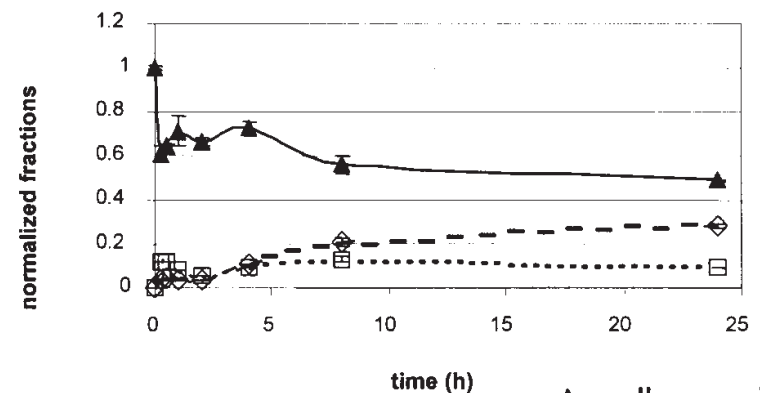

(B) [125]]PIB-A33

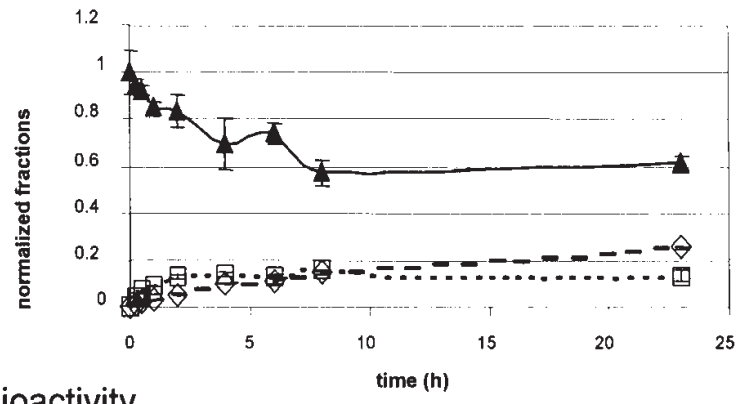

(C) ${ }^{76} \mathrm{Br}-\mathrm{A} 33$

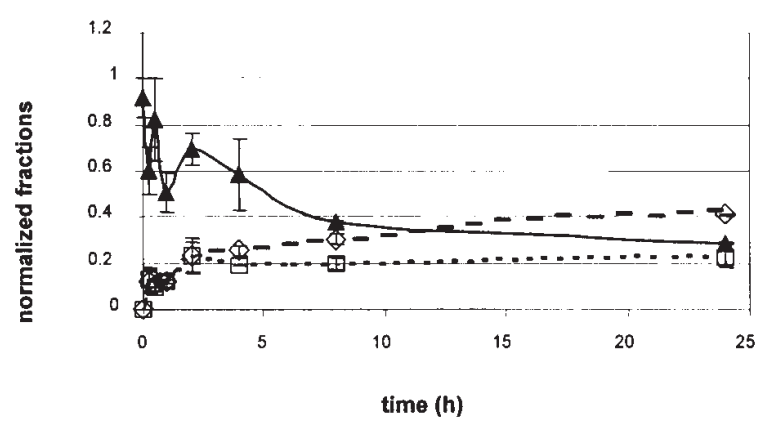
口=released HMW radioactivity $\diamond=$ released LMW radioactivity

Figure 3. Excretion of radioactivity from cells as a function of time for the four conjugates $\left[{ }^{76} \mathrm{Br}\right] \mathrm{PBrB}-\mathrm{A} 33$ (A), $\left[{ }^{125} \mathrm{I}\right] \mathrm{PIB}-\mathrm{A} 33$ (B), ${ }^{76} \mathrm{Br}-\mathrm{A} 33$ (C) and ${ }^{125} \mathrm{I}-\mathrm{A} 33$ (D). $\Delta--\mathbf{\Lambda}$, total cell-associated radioactivity; $\diamond--\diamond$, low molecular weight; and $\square \cdots \square$, high molecular weight released radioactive products. Means and maximum errors are shown for 1 experiment, performed in triplicate.

As indicated in Fig. 1 the cellular uptake pattern of the four conjugates was fairly similar. However, the absolute uptake of the radiolabelled $\mathrm{mAb}$ depended on the labelling method. A possible explanation for the greater absolute uptake of indirectly vs. directly labelled $\mathrm{mAb}$ in the present study is that indirect labelling might cause less damage to the protein. The indirect labelling used in the present study conjugates the radiohalogenated linker molecule to lysine residues of the protein, while direct labelling introduces the radiohalogen into the tyrosine moieties of the protein. Many antibodies, including A33, are known to have an increased fraction of tyrosine residues at the antigen-binding site while the lysine residues are more evenly distributed throughout the antibody (21). Several earlier studies (22-24) have actually shown that the affinity of radiolabelled $\mathrm{mAb}$ may depend on the experimental protocol and experimental conditions rather than the properties of the mAb itself.

The difference in retention between directly and indirectly halogenated mAb A33, as demonstrated in Fig. 2, could have several explanations. It might be caused partly by different time-patterns in the release of membrane-bound mAb. The biexponential shape of the dissociation curves with a rapid early and a slow late phase agrees closely with previously published data $(22,23,25)$. The reason for the bi-phase dissociation curves is not known definitely, but one explanation, suggested by Mattes (23) may be that a fraction of the mAb is monovalently bound and represents the first rapid dissociation. Monoclonal Abs bind predominantly bivalently to the cell surface and wobble at a significant rate to generate a transient, monovalently bound form. Antibodies labelled by different methods differ in their binding behaviour in that the fraction of antibody released intact can differ (26) possibly as a result of complete destruction or hampered function of one binding site by a particular labelling, as mentioned above. It has been shown (25) that Fab fragments dissociated much more rapidly than the intact mAbs, indicating the need of bivalent attachment for irreversible binding.

Another explanation for the differing retention of radioactivity after indirect vs. direct radiohalogenation may be differences in the cellular processing of radiolabelled degradation products. The cellular processing of internalized mAb, shown in Fig. 3, elucidates the differing intracellular retention of degradation products between the two labelling methods. The results show a pronounced retention of internalized radioactivity in the case of indirect labelling as compared with direct labelling. Furthermore, the results in Figs. 2 and 3 demonstrate a difference in release of HMW and LMW radioactivity for the two labelling methods. In Fig. 2, the results reflect the sum of dissociated membrane bound and intracellularly processed $\mathrm{mAb}$ whereas, in Fig. 3, the results reflect intracellularly processed $\mathrm{mAb}$.

mAb A33 is thought to be internalized, upon binding to the A33 antigen, into a not yet fully-characterized large cytoplasmic vesicular compartment, a so-called micropinosome $(13,14)$, in contrast with the majority of mAbs which, after internalisation, are transported to lysosomes where they are metabolised (27). The subcellular distribution of mAb A33 upon internalization into A33 antigen-positive cells has been examined (13), revealing that up to $40 \%$ of total bound $\mathrm{mAb}$ A33 accumulates in these cytoplasmic vesicles, which traverse 
the cytoplasm and come into close proximity with the cell nucleus (13). In the present study, the fraction of internalized radioactivity (approximately one-third of total bound) tallies closely with previously published data.

The fact that HMW radioactivity was released from cells that were treated with excess unlabeled $\mathrm{mAb}$ at $4^{\circ} \mathrm{C}$ to displace membrane-bound mAb (Fig. 3) indicates an excretion of internalized intact mAb. It has been claimed (28) that part of the internalized mAb A33 can be exteriorized in an intact form and thus bind back to the cell surface so that the process of uptake and internalization can be repeated.

Indirect labelling resulted in greater absolute uptake and prolonged intracellular retention of the radiolabel, when compared with direct labelling. Furthermore, no difference in cellular uptake and retention was observed between the two halogens, bromine and iodine. The cellular processing of the radiohalogens thus depends on the labelling method used rather than on the halogen itself. The more favourable retention of the indirectly radiohalogenated mAb compared with directly labelled may be beneficial in vivo for some antibodies.

\section{Acknowledgements}

The authors would like to thank the staff at the Uppsala University PET Center for their assistance with the radiobromine production and the The Svedberg Laboratory for allowing us to use their facilities. This study was supported by the Swedish Cancer Society.

\section{References}

1. Lovqvist A, Sundin A, Roberto A, Ahlstrom H, Carlsson J and Lundqvist H: Comparative PET imaging of experimental tumors with bromine-76-labeled antibodies, fluorine-18-fluorodeoxyglucose and carbon-11-methionine. J Nucl Med 38: 1029-1035, 1997.

2. Lovqvist A, Sundin A, Ahlstrom H, Carlsson J and Lundqvist H: ${ }^{76} \mathrm{Br}$-labeled monoclonal anti-CEA antibodies for radioimmuno positron emission tomography. Nucl Med Biol 22: 125-131, 1995.

3. Lovqvist A, Sundin A, Ahlstrom H, Carlsson J and Lundqvist H: Pharmacokinetics and experimental PET imaging of a bromine76-labeled monoclonal anti-CEA antibody. J Nucl Med 38: 395-401, 1997.

4. Lee FT, Hall C, Rigopoulos A, Zweit J, Pathmaraj K, O'Keefe GJ, Smyth FE, Welt S, Old LJ and Scott AM: Immuno-PET of human colon xenograft-bearing $\mathrm{BALB} / \mathrm{c}$ nude mice using ${ }^{124}$ I-CDR-grafted humanized A33 monoclonal antibody. J Nucl Med 42: 764-769, 2001

5. Hoglund J, Tolmachev V, Orlova A, Lundqvist $\mathrm{H}$ and Sundin A: Optimized indirect ${ }^{76} \mathrm{Br}$-bromination of antibodies using $\mathrm{N}$ succinimidyl para- $\left[{ }^{76} \mathrm{Br}\right]$ bromobenzoate for radioimmuno PET. Nucl Med Biol 27: 837-843, 2000.

6. Sundin J, Tolmachev V, Koziorowski J, Carlsson J, Lundqvist H, Welt S, Larson $\mathrm{S}$ and Sundin A: High yield direct ${ }^{76} \mathrm{Br}-$ bromination of monoclonal antibodies using chloramine-T. Nucl Med Biol 26: 923-929, 1999.

7. Tolmachev V, Orlova A and Lundqvist H: Optimization of iodination of $\left[{ }^{125} \mathrm{I}\right]-\mathrm{N}$-succinimidyl-para-iodobenzoate using Chloramine-T for labeling of proteins. J Radioanalytical Nucl Chem 246: 207-213, 2000.

8. Bolton AE: Radioiodination techniques. Amersham, UK, 1985.

9. Zalutsky MR, Noska MA, Colapinto EV, Garg PK and Bigner DD: Enhanced tumor localization and in vivo stability of a monoclonal antibody radioiodinated using $\mathrm{N}$-succinimidyl 3-(tri-n-butylstannyl)benzoate. Cancer Res 49: 5543-5549, 1989.
10. Orlova A, Höglund J, Lubberink M, Lebeda O, Gedda L, Lundqvist $\mathrm{H}$, Tolmachev $\mathrm{V}$ and Sundin A: Comparative biodistribution of the radiohalogenated $(\mathrm{Br}, \mathrm{I}$ and $\mathrm{At}$ ) antibody A33. Implications for the in vivo dosimetry. Cancer Biother Radiopharm 17: 385-396, 2002.

11. Almqvist Y, Orlova A, Sjöström A, Jensen HJ, Lundqvist H, Sundin A and Tolmachev V: In vitro characterization of ${ }^{211} \mathrm{At}-$ labeled antibody A33 - a potential therapeutic agent against metastatic colorectal carcinoma. Cancer Biother Radiopharm 20: 514-523, 2005.

12. Garin-Chesa P, Sakamoto J, Welt S, Real FX, Rettig WJ and Old LJ: Organ-specific expression of the colon cancer antigen A33, a cell surface target for antibody-based therapy. Int J Oncol 9: 465-471, 1996

13. Daghighian F, Barendswaard E, Welt S, Humm J, Scott A, Willingham MC, McGuffie E, Old LJ and Larson SM: Enhancement of radiation dose to the nucleus by vesicular internalization of iodine-125-labeled A33 monoclonal antibody. J Nucl Med 37: 1052-1057, 1996.

14. Moritz RL, Ritter G, Catimel B, Cohen LS, Welt S, Old LJ, Burgess AW, Nice EC and Simpson RJ: Micro-sequencing strategies for the human A33 antigen, a novel surface glycoprotein of human gastrointestinal epithelium. J Chromatogr A 798: 91-101, 1998.

15. Harapanhalli RS, Schafranek W, Ong GL and Mattes MJ: Lysine-directed radioiodination of proteins with a cyanuric chloride derivative of aminofluorescein. Anal Biochem 231: 50-56, 1995.

16. King DJ, Antoniw P, Owens RJ, et al: Preparation and preclinical evaluation of humanised A33 immunoconjugates for radioimmunotherapy. Br J Cancer 72: 1364-1372, 1995.

17. Heath JK, White SJ, Johnstone CN, Catimel B, Simpson RJ, Moritz RL, Tu GF, Ji H, Whitehead RH, Groenen LC, Scott AM, Ritter G, Cohen L, Welt S, Old LJ, Nice EC and Burgess AW: The human A33 antigen is a transmembrane glycoprotein and a novel member of the immunoglobulin superfamily. Proc Natl Acad Sci USA 94: 469-474, 1997.

18. Koziorowski J, Henssen C and Weinreich R: A new convenient route to radioiodinated $\mathrm{N}$-succinimidyl 3- and 4-iodobenzoate, two reagents for radioiodination of proteins. Appl Radiat Isot 49: 955-959, 1998.

19. Tolmachev V, Lovqvist A, Einarsson L, Schultz J and Lundqvist $\mathrm{H}$ : Production of ${ }^{76} \mathrm{Br}$ by a low-energy cyclotron. Appl Radiat Isot 49: 1537-1540, 1998.

20. Orlova A, Bruskin A, Sjostrom A, Lundqvist H, Gedda L and Tolmachev V: Cellular processing of ${ }^{125} \mathrm{I}$ - and ${ }^{111}$ in-labeled epidermal growth factor (EGF) bound to cultured A431 tumor cells. Nucl Med Biol 27: 827-835, 2000.

21. Nikula TK, Bocchia M, Curcio MJ, Sgouros G, Ma Y, Finn RD and Scheinberg DA: Impact of the high tyrosine fraction in complementarity determining regions: measured and predicted effects of radioiodination on IgG immunoreactivity. Mol Immunol 32: 865-872, 1995.

22. Ong GL and Mattes MJ: Re-evaluation of the concept of functional affinity as applied to bivalent antibody binding to cell surface antigens. Mol Immunol 30: 1455-1462, 1993.

23. Mattes MJ: On the validity of 'functional affinity' determination for antibodies binding to cell surface antigens or other polyvalent antigens. Cancer Res 55: S5733-S5735, 1995.

24. Kaufman EN and Jain RK: Effect of bivalent interaction upon apparent antibody affinity: experimental confirmation of theory using fluorescence photobleaching and implications for antibody binding assays. Cancer Res 52: 4157-4167, 1992.

25. Kyriakos RJ, Shih LB, Ong GL, Patel K, Goldenberg DM and Mattes MJ: The fate of antibodies bound to the surface of tumor cells in vitro. Cancer Res 52: 835-842, 1992.

26. Shih LB, Thorpe SR, Griffiths GL, Diril H, Ong GL, Hansen HJ, Goldenberg DM and Mattes MJ: The processing and fate of antibodies and their radiolabels bound to the surface of tumor cells in vitro: a comparison of nine radiolabels. J Nucl Med 35: 899-908, 1994.

27. Mattes MJ, Griffiths GL, Diril H, Goldenberg DM, Ong GL and Shih LB: Processing of antibody-radioisotope conjugates after binding to the surface of tumor cells. Cancer 73: 787-793, 1994.

28. Barendswaard EC, Humm JL, O'Donoghue JA, Sgouros G, Finn RD, Scott AM, Larson SM and Welt S: Relative therapeutic efficacy of ${ }^{125} \mathrm{I}$ - and ${ }^{131}$ I-labeled monoclonal antibody A33 in a human colon cancer xenograft. J Nucl Med 42: 1251-1256, 2001. 